\title{
Matching Core Competencies To Key Success Factors In Odl, Some Views From The Zimbabwe Open University
}

\author{
Daniel Ndudzo ${ }^{1}$ and Tabitha Zinyama ${ }^{2}$ \\ ${ }^{1}$ Registrar, Zimbabwe Open University, Zimbabwe \\ ${ }^{2}$ Regional Director, Zimbabwe Open University, Mashonaland East, Zimbabwe
}

\begin{abstract}
Open and Distance Learning (ODL) is increasingly being incorporated into many Zimbabwean college and university programmes. The Zimbabwe Open University $(\mathrm{ZOU})$ is the only fully fledged open and distance learning University in Zimbabwe. This study assesses the core competencies of the ZOU with a view to establishing whether these match critical success factors in ODL. The study employs a case study approach where documentary evidence and the author's experiences are the main sources of information. The critical success factors in ODL identified in this study include technology related factors, learning approach, course related factors and learner support services. The study revealed that the main competencies of the ZOU are its capacity to deploy in different geographical areas for the convenience of learners, the ability to produce learning materials and a comprehensive learner support system. The University also has competent and experienced staff, a strong brand which has continued to attract students and staff even when some programmes had been suspended, resource mobilization, vibrant alumni, sound industrial relations, advisory boards, an established research department and research culture, good marketing and public relations function, an established quality assurance department and other human resources related competencies. With the above mentioned competencies, the ZOU has made significant progress in matching its competencies with the critical success factors in ODL. It is recommended that the University introduces ethics workshops for employees so as to reduce negative publicity about ZOU employees. It is also recommended that the University increases consultation and cooperation with regulatory authorities. To increase enrolment of foreign students, the University should leverage on its resourceful ICT department to provide online courses and tutorials.
\end{abstract}

\section{Introduction}

Open and Distance Learning (ODL) is the fastest growing mode of delivery in the higher and tertiary education sector in Zimbabwe. Though the Zimbabwe Open University (ZOU) is the only open and distance learning University in Zimbabwe, other universities are now offering programmes on a distance learning basis, most notably the Midlands State University and NUST who are offering parallel programmes in Harare and other areas.

While the open distance learning sector is experiencing growth at an international level, it is still at its infancy in Zimbabwe with ZOU having been established in 1999. Organizations are still perfecting competitive strategies and developing capabilities. The increase in the number of players in the distance education market requires Universities to think strategically in their competitive strategies. Universities need to develop unique un-imitable strengths which guarantee a sustainable competitive advantage taking into consideration the key success factors in the ODL market.

Effective deployment of distance learning requires institutions to possess certain competencies. These include the capacity to deploy in different geographic areas, effective marketing, robust ICT, a reputable brand, ability to produce learning materials, and an effective research function among other competencies.

Fitzpatrick, 2001 argues that the success of distance education institutions depends on their ability to reach a broader student audience, satisfy student needs and operate efficiently.

The study thus evaluates whether the competencies of the ZOU match the critical success factors in ODL.

\section{Statement of the problem}

Success in Open and Distance Learning requires the development of specific competencies which are relevant to the critical success factors in the ODL field. This study aimed at assessing the core competencies of ZOU with a view of establishing whether these match critical success factors in ODL.

\section{Purpose of the study}

The study aims to match the competencies of the ZOU to the critical success factors in ODL.

\section{Objectives of the Study}

The study sought to achieve the following objectives; 
- To identify the key success factors in ODL

- To identify the Zimbabwe Open University's core competencies

- To match the Zimbabwe Open University’s core competencies to critical success factors in ODL.

The study was guided by the following questions;

\section{Research questions}

- What are the key success factors in ODL?

- What are the Zimbabwe Open University's core competencies?

- To what extent do the Zimbabwe University core competencies match critical success factors in ODL?

\section{Justification of the study}

Studies have been carried out that have identified some of the critical success factors in ODL but these have been limited to Europe and America. These studies have been general and they do not necessarily apply to the African and Zimbabwean context particularly. ODL institutions in Zimbabwe and Africa need to build competencies which suit the variables in the relevant market and the needs of the customers. This study will thus give a more relevant guide to Zimbabwean and African ODL institutions in building competencies relevant to succeed in ODL.

The study gives the ZOU an essential analysis of its competencies. The study evaluates the extent to which the University's competencies match the critical success factors in ODL and recommends specific competencies for development which will enable the University to improve its competitiveness.

\section{Review of related literature}

Prahalad and Hamel (1990) defined a core competence as something unique that a firm has, or can do, strategically well. The concept of core competencies was derived from Barney (1991)'s idea that an organisation's inimitable and valuable tangible and intangible assets are key aspects of a firm's sustainable competitive advantage.

The core competencies model by Prahad and Hamel (1990) encourages managers to develop competitiveness by determining the unique assets that can be used to offer value to customers. As opposed to Porter's 5 forces model that takes an outside-in approach, taking the external environment as the starting point of strategy development, the core competencies model assumes that competitiveness is determined by a company's ability to build core competencies that develop unanticipated products at lower cost and more speedily than competitors.

The literature reviewed indicated that there are several factors which determine the success of Open and Distance Learning institutions. Bekele (2008) developed a model which was based on 82 studies published in educational technology journals between 1995 and 2006. In his model, Bekele (2008) suggests that, success in the ODL is determined by human, technological, course, pedagogic, and leadership factors.

\subsection{Technology-related factors}

Bekele \& Menchaca (2008) and Soong et al., (2001) indicated that the use of multiple technologies in different contexts was crucial for success in ODL. The technologic tools cited include synchronous, asynchronous, and multimedia based tools. Studies by Lammintakanen \& Rissanen, (2005); Pituch \& Lee, (2006); Salter, (2005); Shih et al., (2006); Weaver, (2008); Yan, (2006) indicated that experience in using technology was crucial for success in ODL. Their studies revealed that more technologically experienced students and instructors were more successful.

\subsection{Course-related factors}

These factors generally refer to quality issues in designing and offering distance learning and online courses. Abel, (2005) argued that clear expectations should be communicated to learners by the University. Ostlund, (2008), indicated that course structure also has an impact on success in open and distance learning as it determines the relevance of the course.

\subsection{Learning approach}

The learning approach adopted in the ODL institutions also determines success in ODL. Naidu (2005) identified general design process and pedagogy as critical to success in ODL. According to Benigno \& Trentin, (2000); Harasim, (1996); Thornburg, (2000), process-oriented and social learning was crucial for success.

\subsection{Support services}


Studies by Gilbert et al., (2007), Salter, (2005) indicated that the level of administrative support available to students and instructors was crucial. Studies by Abel, (2005); Baker and Schihl (2005) and Howell and Wilcken, (2005) revealed that student and faculty support services also impacted success. The specific factors identified in these studies include helpdesks, support teaching staff, technical training, faculty professional development opportunities, and update of the technologic pool.

The literature above identifies some of the critical success factors in open and distance education in the context of the European and American environments. These are determined by the variables in the developed economies. The critical success factors then determine the competencies required by European, American or ODL universities in the developed world. What determines success in the developed economies may not necessarily have the same effect in developing countries like Zimbabwe because of the different environmental variables.

This study contexualises the critical success factors and the core competencies to the requirements for success in an African and Zimbabwean ODL context. It thus attempts to close the geographic and variable gaps. The study also closes the information gaps as it documents the core competencies required for a Zimbabwean ODL university.

\section{Methodology}

This study was based on the case study method which falls within the qualitative research paradigm. The study was underpinned by the intepretivist philosophy. Data collection was conducted using three major techniques which are document analysis, direct and participant observation by the researchers who are also members of the management team. Data was also collected through interviews with some of the Zimbabwe Open University senior management. The methods of data collection cited above have been criticized basing on the view that there is a higher likelihood of bias. It should however be noted that the chosen research methodology and data collection techniques provide a greater insight and therefore an opportunity for an in depth analysis of the complex organisational and social aspects of the University.

\section{Competencies of the Zimbabwe Open University \\ 9.1 Ability to produce learning materials}

\section{Research findings}

Evidence obtained through observations show that ZOU produces its own modules to facilitate learning. According to the ZOU website the university commissioned a printing press with the capacity to produce at least 400 modules per day. The investment enables the University to produce learning materials at a significantly lower cost.

Tutorials letters issued to students at beginning of each semester state that learners do not attend lectures. They are given a registration package composed of modules, assignments and a tutorial letter. The Zimbabwe Open University lecturers write modules on behalf of the University. The University operates a printing press with the capacity to print 400 modules per day. A research carried out by Ndudzo (2013) on Learner support services at ZOU revealed that modules are regarded by $80 \%$ of ZOU learners as very useful for distance learning and contribute significantly to learner satisfaction. This is in line with findings in various studies which have ascertained that technology is crucial for success in ODL (Lammintakanen \& Rissanen, 2005; Pituch \& Lee, 2006; Salter, 2005; Shih et al., 2006; Weaver, 2008; Yan, 2006)

ZOU modules are regarded as of high quality and are often purchased by non-ZOU students for their own studies. The University thus has potential not only to generate considerable revenue from selling learning materials but to attract learners to the ODL mode of delivery.

\subsection{The capacity to deploy in different geographical areas}

ZOU operates through the National Centre based in Harare, 10 Regional Centres in the 10 regions of the country and a Virtual Region which provides service to international students. Research carried out by Ndudzo (2013) on Push and Pull factors in ODL service delivery revealed that $89 \%$ of ZOU learners are married and $93 \%$ are employed. This implies that the ODL learner may not be willing to re-locate to another geographical area in pursuit of academic progression because of work and family commitment. The same survey indicated that $91 \%$ of ZOU learners chose to learn through ZOU's ODL programmes because the University is accessible as it has regional centres nearer to their work places and residential areas. $98 \%$ of ZOU learners chose ODL because it is convenient thus they can learn while attending to other responsibilities. This is a competency that many conventional institutions may not ne able to imitate easily as it requires substantial financial resources.

The University is in the process of acquiring a new building for the ZOU national Centre and refurbishing Regional Centre facilities as part of its goal of establishing a state of the art Home for ZOU. Significant progress has been made in construction work in Regional Centres with some of the new buildings awaiting to be opened. 


\subsection{Robust ICT strategy}

ZOU has installed internet connectivity in all its Regional Centres and availed computer labs with internet for its students. ZOU learners can apply and register conveniently online and they can access the electronic library. The University also delivers learning materials to its students online. The University's ICT department has been integral to the learner support system. The ICT department is responsible for the Regional Centre computer labs, installation and maintenance of the internet and other services.

Though the University has established student-centered online administrative services, it is yet to develop platforms to deliver on-line courses, on-line tutor-lab, and additional training for distance learning professors. These are essential competencies required to serve international learners more effectively.l

\subsection{Competent human resources}

The Zimbabwe Open University has the ability to recruit top professors. The University has developed attractive conditions of service packages that have enabled it to retain most of its senior academics and at the same time recruit more professors and Phd holders

The commitment to increase senior academics is mentioned in the University' Strategic Plan 20102014 document and has been vigorously followed up by senior management. The University has managed to keep its senior academics; statistics show that the staff turnover rate at ZOU is very low especially at the level of Academics.

The University is lead by a competent leadership as reflected by the achievements by the University' Vice Chancellor who leads the institution by example. During the period 2011-2013, the Vice Chancellor received three international awards for outstanding contribution to open and distance education at an international level. A University's reputation is hugely influenced by the achievements of its senior academic staff complement.

\subsection{Effective Marketing and Communications Department}

The ZOU Communications and marketing department is responsible for coordinating all University communication with its stakeholders. The department is also at the forefront of the University's efforts to high maintain learner and other stakeholders' engagement with the University. The department plays a crucial role in recruitment of new learners as the University pursues its growth targets.

\subsection{Good brand image}

The ZOU brand is a reputable brand which is trusted by learners. This has seen enrollment growing to above 20000 students in 2006. ODL learners do not frequently engage the institution directly hence the perceived high risk attached to distance education institutions. Distance education is conducted beyond national boundaries through online learning platforms. A trustworthy reputable brand is thus essential to reduce the reputation risk often attached to ODL institutions by learners.

Though the University has a reputable brand, it has only managed to penetrate into the adult market. According to a research carried out by Ndudzo (2013) on Push and Pull factors in ODL, 73\% of ZOU students are above 30 years thus the University has not managed to effectively leverage its brand in attracting A-level and O-level graduates.

\subsection{Quality orientation}

The University cooperates very closely with regulatory authorities and other stakeholders such as Zimbabwe Council for Higher Education (ZIMCHE), Standards Association of Zimbabwe (SAZ) and others involved in standards in Higher Education. The Zimbabwe Open University has a high dedication for quality in its operations.

The University thus has established a Quality Assurance department which oversees conformance of the University to quality standards and requirements of regulatory authorities. All ZOU policies, procedure manuals, modules and other important documents are reviewed by the Quality Assurance department before they are used in the institution or before they are used for service delivery purposes.

In recognition of the University's outstanding commitment to quality, the Zimbabwe Open University received the International Quality Crown Award from the Business Initiative Directors (BID) in November 2012.

The University has been consulted and played a significant role in the development of Open and Distance Learning in Africa. For this ZOU received a special award for its contribution towards the development of Open and Distance Learning at the Open University of Tanzania.

\subsection{An effective learner support system}

The Zimbabwe Open University offers learner support system which is composed of comprehensive academic and non academic learner support services.

The nature of distance education requires an active learner support system which enables effective learnerlearner and learner-tutor interaction. An assessment of learner support services at ZOU study by Ndudzo (2013) 
and studies carried out by Chakuchichi et al (2011) revealed that learner satisfaction is enhanced more by effective academic support services such as tutorials printed learning materials and a well resourced library.

Distance learners without an effective platform for interaction with other learners, tutors and University administrators may feel isolated. Learner isolation may result in high rates of failure and consequently high drop-outs. ZOU thus through its learner support system constantly engages learners.

The University has a website where learners keep posted on events, get study guides and other essential information. ZOU is also active on social networks; learners can get real time updates and interact with University administrators through the University Face book page. The University flights weekly adverts through the print media in the country's major daily newspapers.

\subsection{Reputable programmes}

The quality and reputation of programmes offered by a University is the flagship of the institution's brand. When an organisation's programmes are regarded as of high quality, the reputation of an institution is enhanced. Questionable programmes harm an institution's brand.

When ZOU's programmes were suspended, enrollment decreased even in other programmes. Students become unsure of the institution's credibility and anxiety grows within the student body regarding their chances of employment using the institution's programmes.

\subsection{Resource Mobilisation}

Because of its geographic dispersion, ODL needs huge capital investments thus the need for an effective Resource Mobilisation function. ZOU has a Resource Mobilisation department which engages with the corporate sector and other financiers. The department also organises functions and activities towards resource mobilization.

\subsection{Sound Industrial Relations which is not normally characteristic of Higher Education}

ZOU has managed to maintain good relations which its employees. Studies by Ndudzo (2013) revealed that the employee satisfaction index at ZOU was sufficiently high at $69 \%$. This has enabled the University to avoid inconveniencies caused by industrial action and employee dissatisfaction.

\subsection{Vibrant Alumni}

The ZOU Alumni has played an important role in positioning the ZOU brand and programmes in industry. The alumni works as the student advocate group on behalf of the University. The Alumni are the ambassadors of the ODL project and have played an important PR role for the University.

\subsection{Advisory boards}

University programmes are only allowed to be launched if they are supported by advisory boards. These provide the opportunity for input from representatives of industry. This therefore ensures that the University launches relevant programmes which will not have problems with regulatory authorities.

\subsection{Sound learner - University relations}

ZOU has managed to maintain relatively good relations with its students at a time when other local universities were plagued by frequent student demonstrations. The University managed to stay in touch with student needs through research and consistent engagement with the Student Representative Council.

\subsection{Sound corporate governance}

Corporate governance determines the approach an institution takes towards its stakeholders. ZOU through its corporate governance principles has managed to operate in an inclusive manner that takes care of its staff, students and other stakeholders. This was achieved through platforms which encouraged participation and inclusivity of stakeholders.

\section{Conclusions}

ZOU has made significant progress in developing the key success factors in ODL. The study revealed that the main competencies of the Zimbabwe Open University are in its ability to produce learning materials, marketing and public relations, a vibrant Alumni, an effective learner support system, and competent human resources as the University has managed to attract top professors, and its capacity to deploy in different geographical areas through the Regional Centres and the Virtual Region.

Though ZOU has developed essential competencies in ODL service delivery, the research revealed that there are several issues that needed to be resolved to consolidate ZOU's position as the leading ODL University in Zimbabwe. The University's image has been tarnished by negative publicity.

Concerns about the quality of ZOU programmes due to the suspension of some of the University's programmes and the unwillingness of the Public Service Commission to employ some of the University's graduates have significantly undermined the credibility of the University and its brand. The general perception about ODL has been that it is of poor quality due to relaxed entry requirements for programmes, this perception compounded with the negative media articles are the biggest challenge faced by the ODL University. The 
University thus need to do more to enhance the capability of its Marketing and Alumni competencies to counter the negative perceptions.

The Zimbabwe Open University has the potential to grow if it leverages on its competencies and manage to counter negative media articles about the institution. The study recommends the following;

\section{Recommendations}

Though ZOU has developed several crucial competencies, it has not sufficiently matched its competencies with key success factors in ODL. This study therefore recommends the following;

10 The University takes proactive action in engaging and consulting regulatory authorities to avoid inconveniences and anxiety that have been endured by the University's graduates from some programmes.

11 The University's Human Resources departments introduce ethics training workshops for all ZOU workers. The workshops should at least educate employees on the effects of negative reports on their private lives on the University's brand.

12 The University should introduce platforms to deliver on-line courses, on-line tutorials, and the requisite training for lecturers and non academic staff who manage the services. These are essential services required to serve international learners more effectively.

13 Enhance the Public relations and marketing functions so as to improve the University's market reach and presence.

14 The University should further integrate more members into its Alumni association so as to increase its capacity to effectively represent the University.

It is hoped that implementation of the above recommendations will enable the Zimbabwe Open University in a re-branding exercise and to further expand its capacity to serve an increasing ODL market.

\section{References}

[1]. Abel, R. (2005). Achieving success in Internet-supported learning in higher education: Case studies illuminate success factors, challenges, and future directions. Lake Mary, FL: Alliance for Higher Education Competitiveness. Retrieved, from http://www.ahec.org/ research/study\%5Freports/IsL0205/TOC.html

[2]. Amberg, M., Fischl, F. \& Wiener, M. (2005). Background of critical success factor research. Friedrich-Alexander-Universitat Erlangen-Nurnberg Working, Paper No 2/2005. Nurnberg, Germany.

[3]. Arabasz, P. \& Bake, M.B. (2003). Evolving campus support models for e-Learning courses. URL http://net.educause.edu/ir/library/pdf/EKF/ekf0303.pdf

[4]. Baker, J.D., \& Schihl, R.J. (2005). Faculty support systems. In C. Howard, J. Boettcher, L. Justice, K. Schenk, P.L. Rogers, \& G.A. Berg (Eds.), Encyclopedia of distance education (Vol. 2,pp. 936-940). Hershey, PA: Idea Group Reference

[5]. Bekele, T.A. (2008). Impact of technology-supported learning environments in higher education: Issues in and for research. Unpublished doctoral dissertation, University of Oslo, Norway.

[6]. Bacsich, P., Bastiaens, T. \& Bristow, S.F. (2009). Reviewing the virtual campus phenomenon: The rise of large-scale e-Learning initiatives worldwide. Heverlee: EuroPACE ivzw. URL http://revica.europace.org/Re.ViCa\%20Online\%20Handbook.pdf

[7]. Benigno, V., \& Trentin, G. (2000). The evaluation of online courses. Journal of Computer Assisted Learning, 16(3), 259-270.

[8]. Cruz, A. \& Implementation and Support Manager. (2010). Key success factors for eLearning implementation resulting from proper planning. URL http://www.shiftelearning.com/key-success-factors-for-elearning-implementation-resulting-from-proper-planning

[9]. Gilbert, J., Morton, S., \& Rowley, J. (2007). e-Learning: The student experience. British Journal of Educational Technology, 38(4), 560-573.

[10]. Harasim, L. (1996). Online education: The future. In T. Harrison \& T. Stephen (Eds.), Computer networking and scholarly communication in the 21st century university (pp. 203-214). Cambridge, MA: MIT

[11]. Howell, S.L., \& Wilcken, W. (2005). Student support services. In C. Howard, J. Boettcher, L. Justice, K. Schenk, P.L. Rogers, \& G.A. Berg (Eds.), Encyclopedia of distance education (Vol. 4, pp. 1687-1692). Hershey, PA: Idea Group Reference.

[12]. Fitzpatrick, R. (2001). Is distance education better than the traditional classroom? Retrieved fromhttp:// www.clearpnt.com/accelepoint/articles/r_fitzpatrick_060101.shtml

[13]. Govindasamy, T. (2002). Successful im-plementation of e-Learning; Pedagogical considerations. The Internet and Higher Education, 4(3-4), 287-299.

[14]. Harasim, L. (2003). Elearning communi-ties of practice for teachers. In the electronic classroom of tomorrow. Columbus, Ohio: EOS Publishing.

[15]. Ingram, H., Biermam, K., Cannon, J., \& Niel \& Waddle, C. (2000). Internalizing action learning: a company perspective. Establishing critical success factors for action learning courses. International Journal of Contemporary Hospitality Management, 12(2), 107-113

[16]. Lammintakanen, J., \& Rissanen, S. (2005). Online learning experiences of university students. In C. Howard, J. Boettcher, L. Justice, K. Schenk, P.L. Rogers, \& G.A. Berg (Eds.), Encyclopedia of distance education (Vol. 3, pp. 1370-1374). Hershey, PA: Idea Group Reference.

[17]. Naidu, S. (2005). Evaluating distance education and e-learning. In C. Howard, J. Boettcher, L. Justice, K. Schenk, P.L. Rogers, \& G.A. Berg (Eds.), Encyclopedia of distance education (Vol. 2, pp. 857-864). Hershey, PA: Idea Group Reference.

[18]. Ostlund, B. (2008). Prerequisites for interactive learning in distance education: Perspectives from Swedish students. Australasian Journal of Educational Technology, 24(1), 42-56.

[19]. Papp, Raymond, (2000). "Critical Success Factors for Distance Learning" AMCIS 2000 Proceedings.

[20]. Pituch, K.A., \& Lee, Y. (2006). The influence of system characteristics on e-learning use. Computers \& Education, $47(2), 222-244$.

[21]. Prahalad, C.K., Hamel, G. (1990), "The core competence of the corporation", Harvard Business Review, Vol. 68 No.3, pp.79-91.

[22]. Salter, G. (2005). Factors affecting the adoption of educational technology. In C. Howard, J. Boettcher, L. Justice, K. Schenk, P.L. Rogers, \& G.A. Berg (Eds.), Encyclopedia of distance education (Vol. 2, pp. 922-929). Hershey, PA: Idea Group Reference. 
[23]. Shih, P., Muñoz, D., \& Sanchez, F. (2006). The effect of previous experience with information and communication technologies on performance in a Web-based learning program. Computers in Human Behavior, 22(6), 962-970.

[24]. Soong, M.H.B., Chan, H.C., Chua, B.C., \& Loh, K.F. (2001). Critical success factors for online course resources. Computers \& Education, 36(2), 101

[25]. Thornburg, D. (2000). Campfires in cyberspace: Primordial metaphors for learning in the $21^{\text {st }}$ century. Retrieved from http://www.tcpd.org/thornburg/handouts/Campfires.pdf

[26]. Weaver, D. (2008). Academic and student use of a learning management system: Implications for quality. Australasian Journal of Educational Technology, 24(1), 30-41.

[27]. Yan, Z. (2006). Different experiences, different effects: A longitudinal study of learning a computer program in a network environment. Computers in Human Behavior, 22(3), 364-380. 